\title{
A Rare Cause of Drug-Resistant Epilepsy and Nonconvulsive Status Epilepticus: Ring Chromosome 20
}

Dirençli Epilepsi ve Nonkonvülsif Status Epileptikusun Nadir Bir Nedeni: Ring 20 Kromozomu Olcay ÜNVER ${ }^{1}$, Serap UYSAL ${ }^{1}$

1. Division of Pediatric Neurology, Dept. of Pediatrics, Cerrahpaşa University Faculty of Medicine, Istanbul, Turkey

\section{ABSTRACT}

Introduction: Ring chromosome 20 presents as a drug-resistant epilepsy syndrome with complex partial seizures and nonconvulsive status epilepticus. Other characteristics are mild to moderate learning disability, and various dysmorphic features. Its diagnosis necessitates a high index of suspicion since the incidence is rare and there is no a specific phenotypic expression.

Case: Here we present a child admitted to our pediatric neurology clinic with complex partial seizures and nonconvulsive status epilepticus. Cytogenic studies revealed ring chromosome 20.

Conclusion: Cytogenic studies should be part of the evaluation in epilepsy patients who presented with drug resistant epilepsy of unknown etiology.

Keywords: ring chromosome 20; drug-resistant epilepsy

\section{$\ddot{O Z E T}$}

Giriş: Ring kromozom 20 antiepileptik ilaçlara dirençli nöbetler ve nonkonvülzif status epileptikus ile prezante olur. Hafif-orta öğrenme güçlüğ̈̈ ve çeşitli dismorfik özellikler eşlik eden diğer bulgulardır. Nadir görülmesi ve spesifik fenotipik özelliğinin olmamast nedeniyle tantsl yüksek şüphe gerektirmektedir.

Olgu: Bu yazıda çocuk nöroloji kliniğimize kompleks parsiyel nöbet ve nonkonvülzif status epileptikus ile başvuran, sitogenetik incelemede ring kromozom 20 tespit edilen bir çocuk hasta sunuldu.

Sonuç: Etiyolojisi belli olmayan antiepileptik ilaçlara dirençli epilepsi ile izlenen hastalarda sitogenetik incelemeler değerlendirmenin bir parçası olmalıdır.

Anahtar Kelimeler: ring kromozom 20; antiepileptik ilaçlara dirençli epilepsi

\section{Contact:}

Corresponding Author: Dr. Olcay Ünver, MD

Address: Fevzi Çakmak Mah. Muhsin Yazıcıoğlu Cad. No: 10 Üst Kaynarca, Pendik, Istanbul, Turkey

Tel: +902166254545

E-mail: olcaymd@hotmail.com

Submitted: 23.11.2015

Accepted: 07.12 .2015

DOI: http://dx.doi.org/10.16948/zktb.42866

\section{INTRODUCTION}

Ring chromosome 20 is a rare chromosomal anomaly characterized by drug-resistant epileptic seizures, behavior disorders and mental retardation (1). Although it is well known that genetic factors play an important role in the etiology of epilepsy, the diagnosis of this rare syndrome is typically delayed or unrecognized since chromosomal analysis is not a routine investigation for patients with epilepsy. Here we present a child diagnosed with ring chromosome 20 who presented with drug-resistant complex partial seizures and nonconvulsive status epilepticus.

\section{CASE}

A 9-year-old boy was admitted with drug-resistant seizures to our pediatric neurology outpatient clinic. He was born at term after an uncomplicated pregnancy to consanguineous parents. He achieved his neurodevelopmental milestones at the expected age; however, hyperactivity was noted recently. There was no family history of seizures or other neurological disorders. He started having seizures about 6 months ago. Seizures occurred several times daily, during both sleep and wakefulness lasting 15-30 seconds. He had different types of seizures including tonic-clonic movements of the extremities, loss of consciousness with a stare gaze followed by a state of fluctuating consciousness and loss of speech lasting 15-20 minutes. He was given several different antiepileptic drugs including valproic acid, vigabatrin, levetirasetam, topiramate, ethosuximide, lamotrigine and carbamazepine without a satisfactory clinical response. Current medications were valproate, vigabatrin and phenytoin. In the last few months the frequency and duration of the seizures is markedly increased. He was hospitalized for seizure control and further investigations. Laboratory tests including ammonia, lactate, pyruvate, biotinidase levels, TANDEM mass spectrometry, urine and blood amino acid chromatography, urinary organic acids were normal. 
A lumbar puncture was performed and cerebrospinal fluid (CSF) glucose level was $63 \mathrm{mg} /$ $\mathrm{dl}(50-80 \mathrm{mg} / \mathrm{dl})$ and CSF protein level $27.3 \mathrm{mg} /$ dl $(15-45 \mathrm{mg} / \mathrm{dl})$. The ratio of CSF glucose to simultaneously measured blood glucose was $0.7(>0.4)$, which ruled out glucose transporter 1 (GLUT-1) deficiency. Serum and CSF exami- nation for autoimmune encephalitis revealed normal results. Interictal electroencephalography (EEG) showed spike and slow wave activity prominent on bilateral centrotemporoparietal regions (Figure 1a) and ictal EEG showed diffuse spike and slow wave activity during complex partial seizures (Figure 1b).

Figure 1: EEG recordings of the patient. Spike and slow wave activity prominent on bilateral centrotemporoparietal regions (a) and diffuse spike and slow wave activity during complex partial seizures (b).

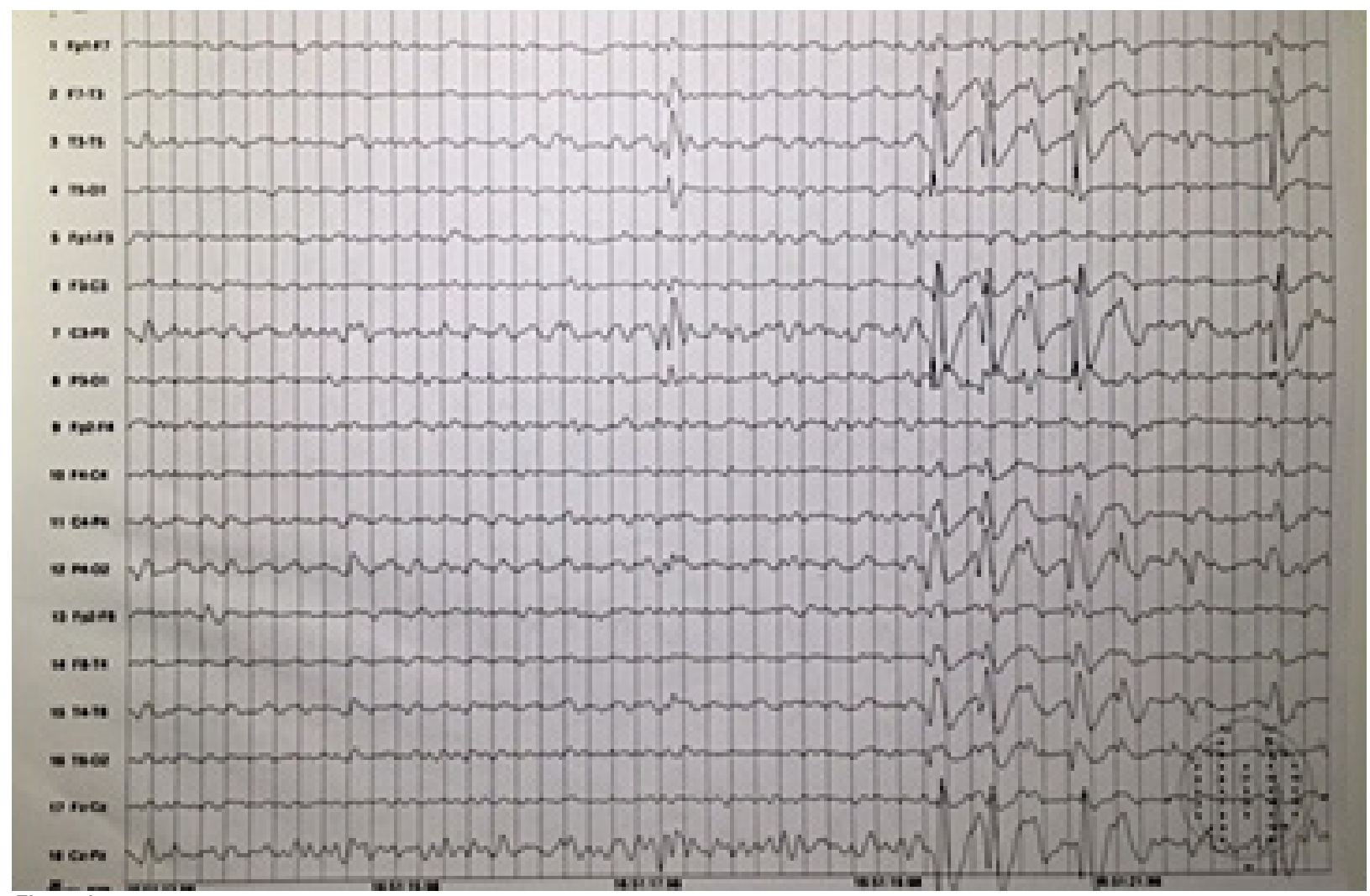

Figure 1a.

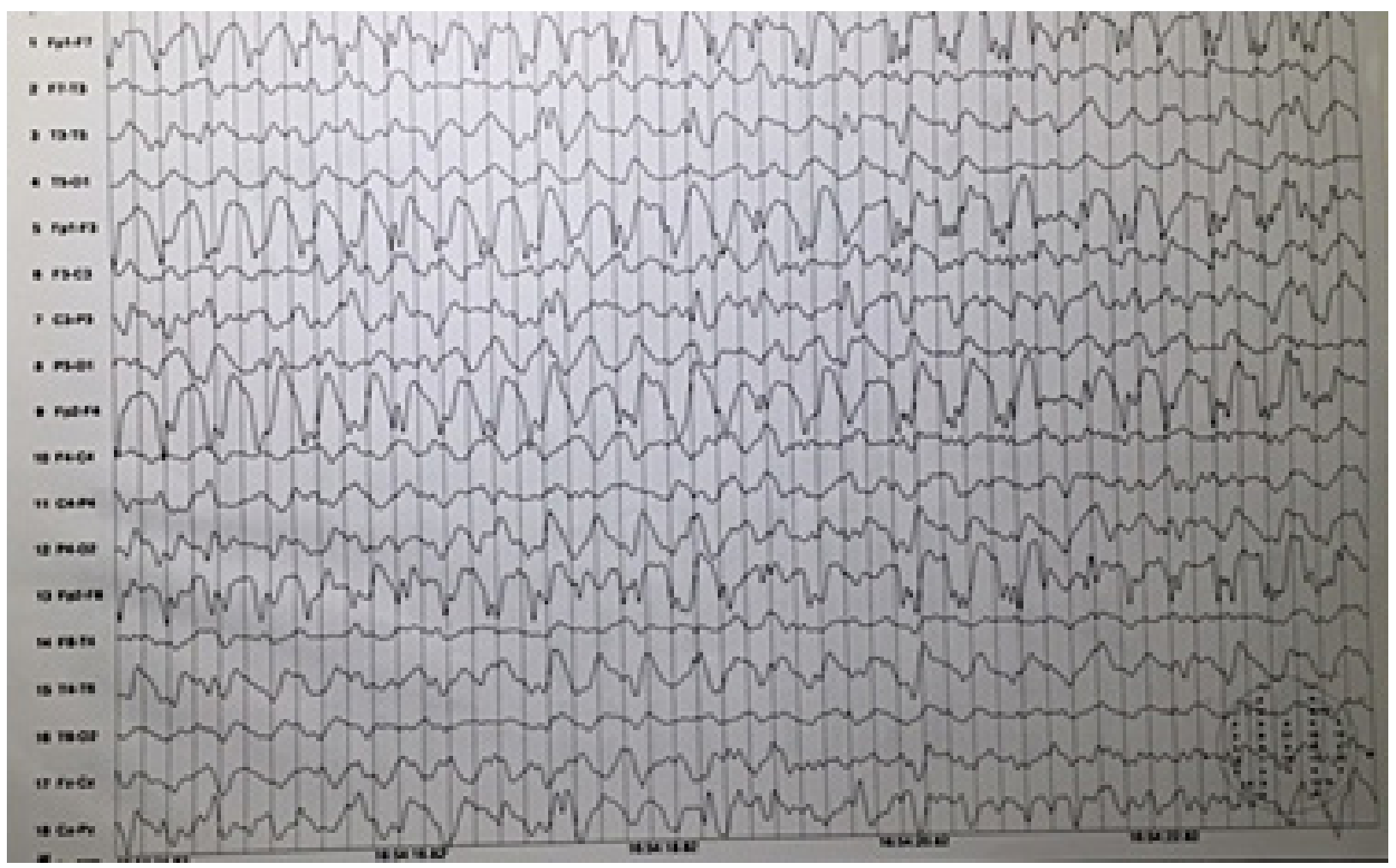

Figure $1 b$. 
Brain magnetic resonance imaging was normal. Cytogenic studies showed the presence of ring chromosome 20 in $15 \%$ of the lymphocytes studied: 46, XY[85]/46, XY, r(20) (p13;q13.3) [15]. He was treated with intravenous midazolam infusion for nonconvulsive status epilepticus. Intravenous methylprednisolone with $20 \mathrm{mg} / \mathrm{kg} /$ day for 5 days followed by $0.4 \mathrm{~g} / \mathrm{kg} /$ day intravenous immunoglobulin with a total dose of $2 \mathrm{~g} / \mathrm{kg}$ were administered for the intractable seizures. Vigabatrin and phenytoin were slowly discontinued and oxcarbazepine was added to the treatment. He was discharged with partial seizure control, 2-3 seizures only occurring during nights, despite different treatment modalities. His IQ was 80 (Wechsler's Adult Intelligence scale).

\section{DISCUSSION}

Ring chromosome 20 was first reported in 1972 (2). It is caused by the fusion of the two arms of the chromosome 20 , which is a result of the deletion of the telomeric regions. The terminal deletion of the long arm involving $20 q 13$ region results in epilepsy (3). Most cases are sporadic only a few are familial (4). The main characteristic feature is the occurrence of drug-resistant seizures (5). The seizures are usually severe with frequent complex partial seizures, nocturnal frontal lobe seizures and nonconvulsive status epilepticus characterized by repetitive episodes of confusional state, lasting to minutes to hours mostly starting before 10 years of age (6). There is no a particular phenotype, however minor dysmorphic features including microcephly, plagiocephaly, genital hypoplasia, dental malocclusions, micrognathia, cauliflower-shaped ears and coarse facial features with slanting eyelids have been reported (7). Variable degrees of cognitive involvement have been described in the literature (1). Cognitive decline is more evident after the beginning of the seizures. Other behavioral abnormalities including hyperactivity and aggressiveness have also been reported in the literature (1). Our patient didn't exhibit any dysmorphic features, however, he had all types of seizures, which are characteristic for the ring chromosome 20 and a borderline IQ and hyperactivity.

The treatment of the seizures is challenging since seizures in this syndrome do not respond well to antiepileptic drugs. A combination of valproate with lamotrigine has been reported to be effective in improving the cognition and treating nonconvulsive status epilepticus (8). Improvement after vagal nerve stimulation has also been reported (9). We achieved only a partial seizure control in our patient with a combination of valproate and oxcarbazepine.
Little is known about the long-term outcomes since there is a limited number of published case reports and case series; however, deterioration in clinical seizures (with evolution to lethal status epilepticus), cognitive status and EEG has been reported after 13-25 years of clinical follow-up (10).

In conclusion, a cytogenic study should be a part of the evaluation in any epilepsy patient presenting with drug-resistant seizures, especially complex partial seizures and nonconvulsive status epilepticus associated with behavior disorders and variable degrees of cognitive deterioration. An early recognition and aggressive treatment of the ring chromosome 20 can allow us a better understanding of the features and long term outcomes of this rare entity.

\section{REFERENCES}

1. Radhakrishnan A, Menon R, Hariharan S, Radhakrishnan $K$. The evolving electroclinical syndrome of "'epilepsy with ring chromosome 20. Seizure 2012;21(2)92-7.

2. Atkins L, Miller WL, Salam M. A ring-20 chromosome. J Med Genet 1972;9:377-80.

3. Phillips HA, Scheffer IE, Berkovic SF, Hollway GE, Sutherland GE, Mulley JC. Localization of a gene for autosomal dominant nocturnal frontal lobe epilepsy to chromosomal 20 q13.2. Nat Genet 1995;10:117-8.

4. Hergård E, Mononen T, Mervaala E, Kuusela L, Aikiä $M$, Stenbäck U, et al. More severe epilepsy and cognitive impairment in the offspring of a mother with mosaicism for the ring 20 chromosome. Epilepsy Res 2007;73-1228 .

5. Alpman A, Serdaroğlu G, Çoğulu O, Gökben S, Özklnay $F$. Ring chromosome 20 syndrome with intractable epilepsy. Dev Med Child Neurol 2005;47:343-6.

6. Gomes Mda M, Lucca I, Bezerra SA, Llerena J Jr, Moreira, DM. Epilepsy and ring chromosome 20: case report. Arq Neuropsiquiatr. 2002;60:631-5.

7. Garcia DM, Ortiz R, Gomez A, Barriuso E. Ring 20 chromosome syndrome with epilepsy and dysmorphic features: a case report. Epilepsia 2001;42:1607-10.

8. Vignoli A, Canevini MP, Darra F, La Selva L, Fiorini E, Piazzini A, et al. Ring chromosome 20 syndrome: a link between epilepsy onset and neuropsychological impairment in three children. Epilepsia 2009;50:2420-7.

9. Chawla J, Sucholeiki R, Jones $C$, Silver K. Intractable epilepsy with ring chromosome 20 syndrome treated with vagal nerve stimulation: case report and review of the literature. J Child Neurol 2002;17:778-80.

10. Jacobs J, Bernard G, Andermann E, Dubeau F, Andermann F. Refractory and lethal status epilepticus in a patient with ring chromosome 20 syndrome. Epileptic Disord 2008; 10:254-9. 